\title{
On-site corrosion monitoring experience in concrete structures: potential improvements on the current-controlled polarization resistance method
}

\author{
『J. E. Ramón 凶, ®Á. Castillo, @I. Martínez \\ Instituto de Ciencias de la Construcción Eduardo Torroja, CSIC, (Madrid, Spain). \\ jose.ramon@ietcc.csic.es
}

Received 19 July 2021

Accepted 9 september 2021

Available on line 15 October 2021

\begin{abstract}
The need for proactive maintenance of reinforced concrete structures with non-destructive testing (NDT) is less disputable today than ever. One of the most promising strategies in this regard is the in-situ measurement of the reinforcement corrosion rate. This study explored the reliability of modulated current confinement method (hereafter MCC) based on a review of in-situ measurements made with that technique in real-life structures over a 13-year period. The most prominent problems detected included defective confinement of the polarization current in low-resistivity environments and over-polarization of passive reinforcement. The findings, which showed enhancement of MCC reliability to depend on improving the electrochemical current regulation and control methodologies presently in place, are being applied to improve the design of the next generation of corrosion meters.
\end{abstract}

KEYWORDS: Concrete; Steel reinforcement; Corrosion; Durability.

Citation/Citar como: Ramón, J.E.; Castillo, A.; Martínez, I. (2021) On-site corrosion monitoring experience in concrete structures: potential improvements on the current-controlled polarization resistance method. Mater. Construcc. 71 [344], e265. https://doi. org/10.3989/mc.2021.11221.

RESUMEN: Experiencia en la monitorización de la corrosión in situ en estructuras de hormigón: posibles mejoras en el método de resistencia a la polarización controlada por corriente. La necesidad de realizar un mantenimiento proactivo de las estructuras de hormigón armado mediante técnicas no destructivas (NDT) es ya un hecho. Una estrategia de interés es la medida de velocidad de corrosión de las armaduras in-situ. El objetivo de este trabajo es realizar un estudio sobre la fiabilidad del método de confinamiento modulado de la corriente (MCC). Para ello se realiza una revisión de las medidas realizadas in situ con dicho método en diferentes estructuras reales a lo largo de 13 años. Las principales problemáticas detectadas son un deficiente confinamiento de la corriente de polarización en situaciones de baja resistividad y una polarización excesiva de las armaduras en estado pasivo. Para incrementar la fiabilidad del método MCC, se identifica la necesidad de mejorar la metodología actual de regulación y control de corrientes. Partiendo de los inputs de este trabajo, estamos ya trabajando en mejoras de los próximos corrosímetros.

PALABRAS CLAVE: Hormigón; Armadura de acero; Corrosión; Durabilidad. 


\section{INTRODUCTION}

With its combination of durability and mechanical strength, reinforced concrete is the world's most widely used structural material today. Reinforcement corrosion is one of the factors that limits the service life of reinforced concrete structures, however. To address that problem European standards such as Eurocode 2 (1) set out limit state-based specifications for reinforced and prestressed concrete structures. Such codes require the inclusion of an inspection and maintenance plan as part of the initial design to ensure performance does not decline below certain minimum values during a structure's service life. The proactive maintenance strategies set out in those plans must envisage periodic inspections to assess the condition of the structure and detect any risk of pathology in advance. Non-destructive testing (NDT), consisting among others in electrochemical techniques for assessing corrosion in this material, is particularly apt for implementing such strategies.

One of the foremost parameters to be assessed is reinforcement corrosion rate to predict the possible effects of steel corrosion on service life by non-destructive methods. Most of the handheld corrosion meters used for on-site measurements deploy electrochemical techniques based on the Stern-Geary linear polarization resistance $\left(\mathrm{R}_{\mathrm{P}}\right)$ method, which is particularly suitable in the presence of low reinforcement polarization. Corrosion potential $\left(\mathrm{E}_{\mathrm{CORR}}\right)$ values ranging from $5 \mathrm{mV}$ to $30 \mathrm{mV}$ are cited in the literature as acceptable for these intents and purposes (2-4). Corrosion density (or rate), $\mathrm{i}_{\mathrm{CORR}}$, in turn, is related to $\mathrm{R}_{\mathrm{P}}$ as shown in Equation [1]:

$$
\mathrm{i}_{\mathrm{CORR}}=\frac{\mathrm{B}}{\mathrm{R}_{\mathrm{P}} \cdot \mathrm{A}}
$$

where $\mathrm{B}$, a constant, may adopt the value of 13 $\mathrm{mV}$ in the presence of active or $52 \mathrm{mV}$ of passive reinforcement. Where the condition of the steel is unknown a mean value of $26 \mathrm{mV}$ is applied $(5,6)$. A is the area $\left(\mathrm{cm}^{2}\right)$ of steel to be measured.

Galvanostatic pulse corrosion meters are among the instruments most widely used to determine corrosion rate. Examples include Gecor (7), patented by patented by CSIC and Geocisa (Spain), and GalvaPulse, a device manufactured by Germann Instruments (Denmark) (8). Both deploy the galvanostatic pulse technique (GPT) to deliver corrosion rate measurements quickly (9) by calculating $R_{p}$ from the potential-time $(E-t)$ curve plotted with the reinforcement polarization values generated during application of a short current pulse.

The values typically recommended in the literature for the current generated by GPT range from $2 \mu \mathrm{A}$ to $50 \mu \mathrm{A}$ for passive reinforcement and from $100 \mu \mathrm{A}$ to $500 \mu \mathrm{A}$ for activated steel (10-13). Pulse duration is normally from $5 \mathrm{~s}$ to $100 \mathrm{~s}$, depending on the condition of the embedded steel (2). Experience has nonetheless shown that as such criteria are not always applicable, they should be deemed to be merely indicative. In practice, the reliability of GPT results tends to depend on operator experience and skill in selecting the parameters best suited to the system studied (14). That may limit the reliability and use of the technique, for the absence of manual parameter adjustment in market corrosion meters induces measurement errors that may result in a misleading diagnosis of structural corrosion.

Measurement reliability is further dependent upon handheld corrosion meter capacity to confine the signal applied to a pre-defined area of the reinforcement (parameter in $A$ of Equation [1]), normally by means of a guard ring. Shortcomings in that respect have been identified in a number of commercial meters (15), whilst comparisons of the readings delivered by such handheld devices have revealed disparities (16), prompting users to question the accuracy of the technique. The Gecor device addresses that problem by the use of the modulated current confinement method (MCC), a method developed in the 1990s that improved in-situ measurements considerably (17). That notwithstanding, experience has again shown that in practice confinement may be less than effective, leading to essentially inaccurate corrosion rate values.

The present authors have devoted over 20 years to on-site structural inspection and in particular to the study of reinforcement corrosion rates, developing and patenting systems to improve corrosion detection in reinforced concrete $(18,19)$. Drawing from the experience accumulated in the over 30 years elapsing since the MCC method was patented (7), the authors have a long experience reflected in various scientific publications (20-25) and which undoubtedly serves as a basis for a critical and constructive analysis regarding the reliability of such on-site inspection methods.

The present study identified the shortcomings that adversely affect the accuracy of the corrosion rate readings obtained with MCC based on a review of the values recorded in situ in 15 real-life structures exposed to different types of environments. MCC reliability was assessed by analyzing the main test parameters: 1) the ratio between the current applied with the counter electrode $\left(\mathrm{I}_{\mathrm{CE}}\right)$ and the guard ring $\left(\mathrm{I}_{\mathrm{XCE}}\right)$ fitted to the corrosion meter, which determines signal confinement efficacy; and 2) the effective polarization potential $\left(\mathrm{E}_{\mathrm{POL}}\right)$ induced in the reinforcement, which determines linear polarization resistance method applicability. The conclusions identify the primary causes of error in MCC and serve as grounds for proposals on how to improve future devices for the on-site inspection of reinforced concrete structures. 


\section{EXPERIMENTAL}

\subsection{Structures Inspected}

Table 1 lists the most prominent characteristics of the structures assessed with MCC to determine their corrosion rate values. Most were inspected during the research team's 13-year lifespan and a few earlier. The 15 structures involved are located in different areas of Spain and exposed to different aggressive environments, classified as per the categories set out in European standard EN 206-1:2000 (26). Although most were inspected on a one-off basis, some were assessed periodically over several years. A total of 1867 measurements were recorded, 891 or nearly half of which for a single structure, the first listed in Table 1. It and the following four structures together summed $75 \%$ of the total readings, whilst the other 10 structures accounted for less than $5 \%$ each.

Inasmuch as non-destructive techniques form part of more comprehensive inspections conducted on the structures studied, in some cases data were also available on concrete electrical resistivity. The Newman method (27) for calculating resistivity for the flow of current to a disk was applied to the reinforced concrete structures studied (28). A sensor with a disk diameter $\left(\phi_{\text {DISC }}\right)$ of $2 \mathrm{~cm}$ and a cell constant $\mathrm{k}=2$ was used to convert electrical resistance $\left(R_{E}\right)$ to resistivity $(\rho)$, assuming $\rho=k \cdot \phi_{\text {DISC }} \cdot R_{E}$. In the cases at issue the total chloride concentration on the concrete surface and at the depth of the first rebar were also found, applying the potentiometer method described in Spanish standard UNE 112010:2011 (29).

\subsection{Corrosion Meter Operating Principle}

The corrosion rates (expressed as corrosion current density, $\mathrm{i}_{\text {CORR }}$ ) of the rebar embedded in the structures listed in sub-section 2.1 were measured in situ with a corrosion meter using the patented modulated current confinement method (MCC) (7). The device used is designed to also measure corrosion potential $\left(\mathrm{E}_{\mathrm{CORR}}\right)$ and electrical resistance of concrete $\left(\mathrm{R}_{\mathrm{F}}\right)$. The applicability of this type of electrochemical techniques to study reinforcement corrosion is based on the material's electrolytic behavior, for the moisture locked in its complex interconnected pore network serves as the aqueous medium through which aggressive external agents penetrate the concrete cover to the embedded steel.

The corrosion meter used was not the commercial device based on the patent, however, but a laboratory prototype designed to manually vary internal measurement parameters such as polarization time and amplitude of the current pulse applied $\left(\mathrm{I}_{\mathrm{AP}}\right)$. The prototype also delivered the values of the parameters characteristic of the test as the readings were taken, enabling researchers to analyze the method exhaustively in each measurement.

TABLE 1. Characteristics of structures monitored.

\begin{tabular}{|c|c|c|c|c|}
\hline Structure id. & Location & $\begin{array}{c}\text { Exposure class } \\
\text { as per EN 206-1:2000 (26) }\end{array}$ & Number of MCC readings & Assessment period \\
\hline 1 & Lleida & $\mathrm{XD1}$ & 891 & $2004-2020$ \\
\hline 2 & Cadiz & $\mathrm{XS} 3$ & 180 & 2019 \\
\hline 3 & Tarragona & $\mathrm{XC} 4$ & 163 & 2016 and 2020 \\
\hline 4 & Barcelona & XS1 & 114 & $2018-2019$ \\
\hline 5 & Tarragona & $\mathrm{XC} 2$ & 87 & $2007-2018$ \\
\hline 6 & Madrid & $\mathrm{XC} 4$ & 82 & 2008 \\
\hline 7 & Vizcaya & $\mathrm{XS} 3$ & 79 & $2005-2013$ \\
\hline 8 & Cantabria & $\mathrm{XC} 4$ & 75 & 2016 \\
\hline 9 & Barcelona & XS1 & 45 & 2009 \\
\hline 10 & Lanzarote & XS1 & 37 & 2014 \\
\hline 11 & Palma de Mallorca & $\mathrm{XS} 3$ & 30 & 2017 \\
\hline 12 & Tarragona & $\mathrm{XC} 2$ & 22 & 2005 \\
\hline 13 & Las Palmas & XS1 & 21 & 2006 \\
\hline 14 & Huesca & $\mathrm{XC} 4$ & 21 & 2004 \\
\hline 15 & Madrid & $\mathrm{XC} 2$ & 20 & 2003 \\
\hline
\end{tabular}


As noted earlier, the corrosion rate measured by the instrument was based on the Stern-Geary linear polarization resistance $\left(R_{p}\right)$ method. The MCC method was used to control the area of reinforcing steel polarized with the galvanostatic pulse technique (GPT). The system entailed positioning a sensor equipped guard ring on the specimen to confine the signal applied to a controlled length of the reinforcement. $\mathrm{R}_{\mathrm{P}}$ is obtained from the potential-time $(E-t)$ response when the reinforcement was polarized with a galvanostatic pulse characterized by amplitude $\mathrm{I}_{\mathrm{AP}}$. The GPT deployed was designed around the equivalent circuit depicted in Figure 1.a proposed by Randles (30) to model steel-concrete systems. Figure 1.b illustrates the potential response typical of that model. To find the $i_{C O R R}$ value, parameter $R_{P}$ in Equation [1] was substituted for its numerical value as found with Equation [2]:

$$
R_{P}=\frac{E_{M A X}-E_{\Omega}}{I_{A P}}=\frac{E_{P O L}}{I_{A P}}
$$

where $\mathrm{E}_{\mathrm{POL}}$ is effective system polarization, obtained by subtracting the ohmic potential drop $\left(\mathrm{E}_{\Omega}\right)$ from maximum polarization $\left(\mathrm{E}_{\mathrm{MAX}}\right)$. The ohmic drop $\left(\mathrm{E}_{\Omega}\right)$ appears as an abrupt variation in potential at the start and end (after interrupting the current) of the $E$ - $t$ curve. Its value is the product of $I_{A P} \cdot R_{E}$, where $\mathrm{R}_{\mathrm{E}}$, concrete electrical resistance, is found from Equation [3]:

$$
R_{E}=\frac{E_{\Omega}}{I_{A P}}
$$

Given that GPT is based on the Stern-Geary method, the $\mathrm{E}_{\mathrm{POL}}$ value must lie within $5 \mathrm{mV}$ and $30 \mathrm{mV}$ for corrosion rate calculations to be deemed correct. And since further to Equation [2], $\mathrm{E}_{\mathrm{POL}}=\mathrm{R}_{\mathrm{P}} \cdot \mathrm{I}_{\mathrm{AP}}$; the $I_{A P}$ value must be adjusted to corrosion kinetics
$\left(\mathrm{R}_{\mathrm{p}}\right)$ to obtain a suitable $\mathrm{E}_{\mathrm{POL}}$. The corrosion meter therefore estimates the current to be applied $\left(\mathrm{I}_{\mathrm{AP}}\right)$ for $\mathrm{E}_{\mathrm{POL}}$ to lie within the desired range, although it is designed to ensure the $\mathrm{I}_{\mathrm{AP}}$ is never under $5 \mu \mathrm{A}$. Pulse duration is an equally important factor, for it must be long enough to reach quasi-stationary status while the reading is being taken $\left(\mathrm{E}_{\mathrm{MAX}} \approx \mathrm{E}_{\infty}\right)$. Here the pulse was applied for $30 \mathrm{~s}$ to $100 \mathrm{~s}$, depending on the characteristics of the steel-concrete system a hand. Pulses of around $30 \mathrm{~s}$ were used for corroded structures and close to $100 \mathrm{~s}$ for passive steel ${ }^{1}$. Although $\mathrm{I}_{\mathrm{AP}}$ was initially set to attempt to optimize $\mathrm{E}_{\mathrm{POL}}$, the value recorded and used to calculate $R_{P}$ (Equation [2]) was the actual post-pulse value, i.e., the $\mathrm{E}_{\mathrm{POL}}$ reading recorded when the current was interrupted (Figure 1.b).

Figure 2 shows the main components of the corrosion meter used for on-site corrosion rate measurements. The electronic element recorded reinforcement corrosion potential $\left(\mathrm{E}_{\mathrm{CORR}}\right)$ and applied the current pulse, $\mathrm{I}_{\mathrm{AP}}$, with a galvanostat. That entailed connecting the instrument to the reinforcement and securing a guard ring to the surface of the structure along the length of rebar to be assessed (Figure 2.a).

The corrosion meter sensor (Figure 2.b) was fitted with a stainless-steel ring-shaped counter electrode (CE) through which the $\mathrm{I}_{\mathrm{AP}}$ current was applied and a $\mathrm{Cu} / \mathrm{Cu}_{2} \mathrm{SO}_{4}$ reference electrode (RE) in the centre to record the E-t response of the rebar, which is considered the working electrode (WE). The sensor also featured a sensorised guard ring to delimit the area of steel polarized (parameter A) to calculate $i_{\text {CORR }}$ from Equation [1]. The guard ring consisted in an external counter electrode (XCE), also a ring-shaped stainless-steel component, through which current $\mathrm{I}_{\mathrm{XCE}}$ is applied opposing that applied through the CE $\left(\mathrm{I}_{\mathrm{CE}}=\mathrm{I}_{\mathrm{AP}}\right)$. The $\mathrm{I}_{\mathrm{XCE}}$ value was adjusted to ensure the electrical field was confined to the area between the two rings on the grounds of the potential recorded by the two $\mathrm{Cu} / \mathrm{Cu}_{2} \mathrm{SO}_{4}$ reference electrodes positioned
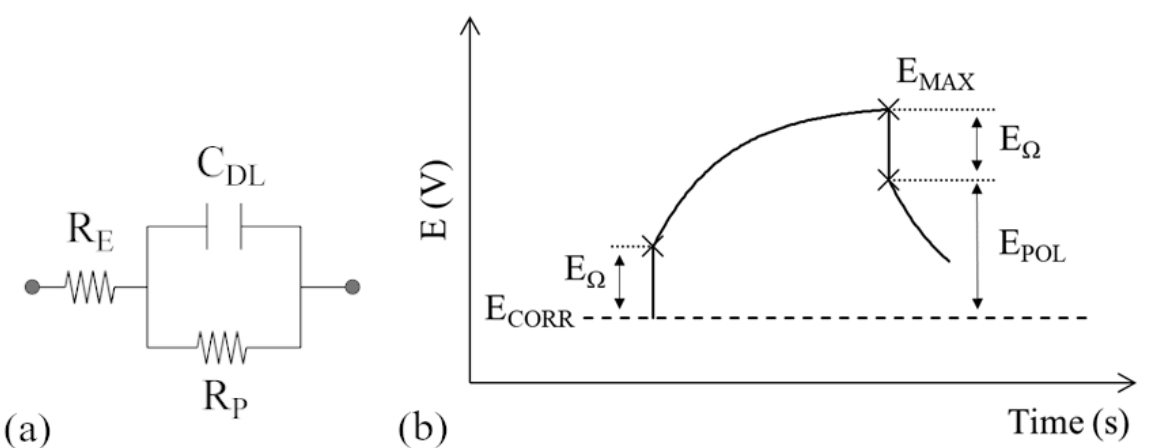

FIGURE 1. (a) Equivalent circuit adopted to model simplified steel-concrete systems for on-site measurement of corrosion rate with a corrosion meter; and (b) potential-time (E-t) response obtained when a galvanostatic pulse is applied in the anodic direction by a corrosion meter.

\footnotetext{
1 In each case, the decision regarding the polarization time is made by the researcher. The criterion is established by the qualitative value of the corrosion potential $\left(\mathrm{E}_{\mathrm{CORR}}\right)$ measured prior to determining the corrosion rate.
} 
Cross-section view of the corrosion meter

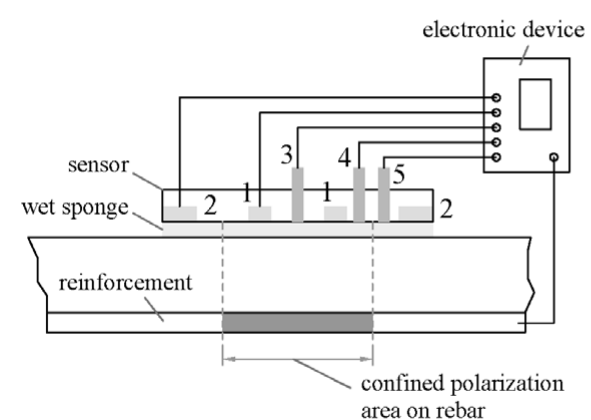

(a)
Sensor underside

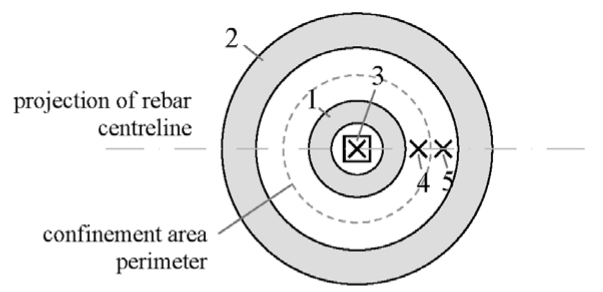

Sensor electrodes

1. Internal counter-electrode $(\mathrm{CE})$

2. External counter-electrode (XCE)

3. Central reference electrode (RE)

4-5. Reference electrodes to monitor confinement

FiguRE 2. Corrosion meter used for on-site reinforcement corrosion rate measurements: (a) cross-section showing the main components of the device and their purpose; and (b) underside of sensor indicating the position of the component electrodes.

between them (Figure 2.b). More specifically, the potential between the two electrodes had to be held at the same value as recorded prior to polarization.

The polarized reinforcement's response to the galvanostatic pulse was received by the electronic element in the corrosion meter, which then processed the information to calculate corrosion parameters $\mathrm{E}_{\text {CORR }}, \mathrm{i}_{\text {CORR }}$ and $\mathrm{R}_{\mathrm{E}}$. The values were displayed on the device screen and stored in its memory.

Parameter $i_{\text {CORR }}$ was found by entering the $R_{p}$ value recorded into Equation [1] and assuming a value of $26 \mathrm{mV}$ for constant $\mathrm{B}$ in all cases. To define the working area (A) the sensor was assumed to project a $10.5 \mathrm{~cm}$ diameter cylinder inward toward the rebar. The length along the latter intersected by the projected cylinder was deemed to be the area where polarization was effective (Figure 2.a). In other words, the A value for each measurement depended on rebar diameter $(\phi)$ and was calculated as:

$$
A\left(\mathrm{~cm}^{2}\right)=10.5 \cdot \pi \cdot \phi
$$

Rebar arrangement in each of the structures listed in sub-section 2.1 was staked out prior to the first inspection. Corrosion meter readings were taken at the points defined to be the most representative or of greatest interest to the study underway at the time of inspection. Those points were identified after fully mapping $\mathrm{E}_{\mathrm{CORR}}$ and electrical resistivity, which furnished qualitative information on the steel condition.

The corrosion meter was connected to the rebar to be assessed in each measurement and connected as well to the sensor on the instrument used to generate polarization (Figure 2). The sensor in turn was positioned on the concrete surface ensuring that the projected centreline of the rebar crossed through the centre of its circumference (Figure 2.b). Moist sponges were placed between the sensor electrodes and the concrete surface to facilitate the electrolytic connection between the measuring electrodes and the pore network in the concrete, which constitute the measuring electrolyte (Figure 2.a).

\subsection{Criteria for Interpreting Measurements}

The reliability of the measurements delivered by the corrosion meter described in sub-section 2.2 was verified by analyzing certain test parameters in two distinct stages of the process:

- Current ratio: confinement system efficacy was verified by analyzing currents $\mathrm{I}_{\mathrm{CE}}$ and $\mathrm{I}_{\mathrm{XCE}}$. Confinement was only deemed valid and the resulting measurement accurate where $\mathrm{I}_{\mathrm{XCE}}>\mathrm{I}_{\mathrm{CE}}$, for $\mathrm{I}_{\mathrm{XCE}}<\mathrm{I}_{\mathrm{CE}}$ would denote system inability to contain the current pulse within the target area.

- Polarization potential: the effective rebar polarization $\left(\mathrm{E}_{\mathrm{POL}}\right)$ was verified. As noted earlier, a number of authors (2-4) contend that $\mathrm{E}_{\mathrm{POL}}$ values must range from $5 \mathrm{mV}$ to $30 \mathrm{mV}$ for the corrosion rate $\left(\mathrm{i}_{\text {CORR }}\right)$ calculated with the linear polarization resistance method to be reliable.

The criteria applied to the $\mathrm{i}_{\text {CORR }}$ findings to determine degree of reinforcement corrosion were as specified in Spanish standard UNE 112072:2011 (31) and standards ASTM STP 1065 (32) and RILEM TC-154-EMC (6). Those findings were also compared to the values for other parameters of interest such as corrosion potential ( $\mathrm{E}_{\mathrm{CORR}}$ ), further to the recommendations set out in (33), and concrete resistivity $(\rho)$ as laid down in (34).

\section{RESULTS}

\subsection{Corrosion Meter Current Ratio}

Figure 3 shows the percentage of measurements in which the ratio between currents $\mathrm{I}_{\mathrm{CE}}$ and $\mathrm{I}_{\mathrm{XCE}}$ could 


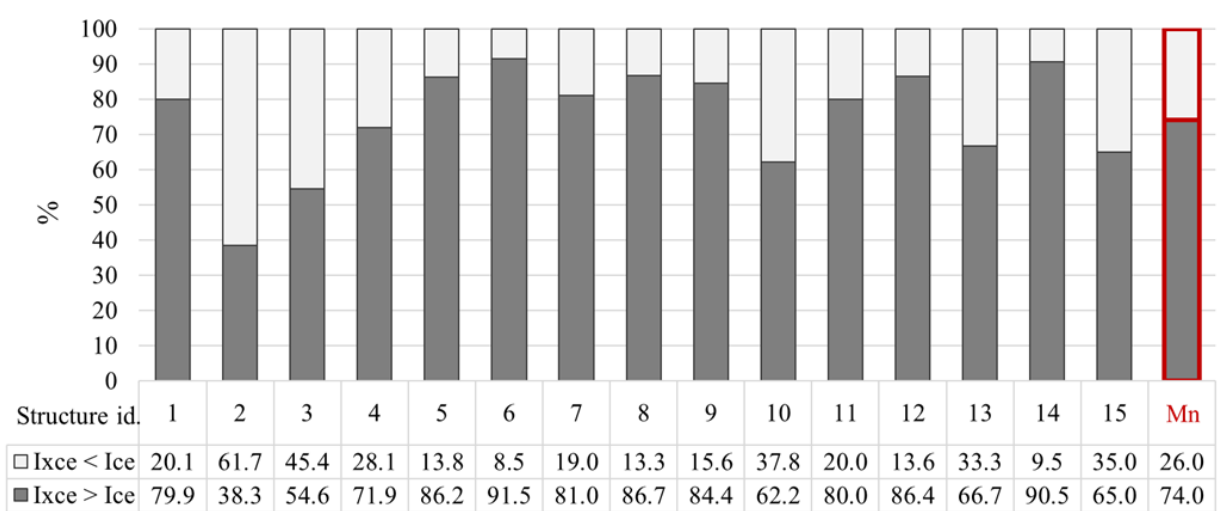

FIGURE 3. Percentage of valid $\left(\mathrm{I}_{\mathrm{XCE}}>\mathrm{I}_{\mathrm{CE}}\right.$ ) and non-valid $\left(\mathrm{I}_{\mathrm{XCE}}<\mathrm{I}_{\mathrm{CE}}\right.$ ) measurements in each structure analyzed and respective mean (Mn) values, further to criteria laid down in sub-section 2.3 on the $\mathrm{I}_{\mathrm{CE}} / \mathrm{I}_{\mathrm{XCE}}$ ratio recorded by the corrosion meter.

be deemed valid for the present purposes, with confinement satisfying the criteria described in sub-section 2.3. Outside of one extreme case (structure 2) where the confinement system was suitable for just $38.3 \%$ of measurements, $54 \%$ to $92 \%($ mean $=74 \%)$ of the readings could be deemed valid on the grounds of the aforementioned inter-current ratio criteria and used for structural assessment and diagnosis.

Non-valid measurements were defined to be those where the corrosion meter guard ring failed to fully confine the pulse. At around $26 \%$, the mean percentage of non-valid measurements might be a statistically assumable error, but in practice would mean readings would have to be taken by a qualified technician able to review each and repeat where necessary. That constraint may limit corrosion meter operability and lengthen structure inspection times.

Cases such as structure 2 may also arise, in which the non-valid rate was clearly lower than the mean. That development may have been related to the shortcomings reported by earlier authors in connection with the performance of ring guard corrosion meters in low electrical resistance $\left(R_{E}\right)$ concretes $(35,36)$, such as found in structure 2 in this study,

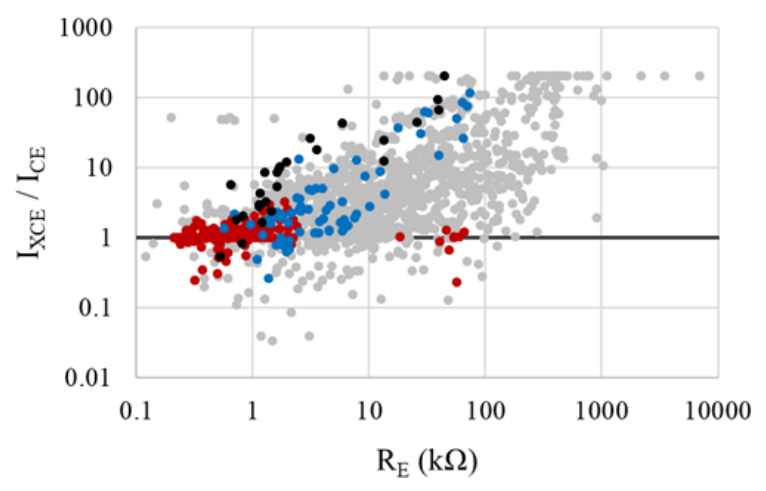

(a) $\bullet$ structure $2 \bullet$ structure $7 \bullet$ structure $11 \bullet$ all other structures exposed to a high chloride (XS3) environment.

The $\mathrm{I}_{\mathrm{XCE}} / \mathrm{I}_{\mathrm{CE}}$ ratio is plotted against concrete electrical resistance $\left(R_{E}\right)$ in Figure $4 . a$ to study that issue in greater depth. The graph shows that as a rule the lower the $\mathrm{R}_{\mathrm{E}}$ the more acute was the tendency for measurements to converge on $\mathrm{I}_{\mathrm{XCE}} / \mathrm{I}_{\mathrm{CE}} \approx 1$, the limit below which the measurement was deemed to be non-valid due to corrosion meter guard ring malfunction. The rate of valid values would therefore be expected to be lower in the presence of low $R_{E}$ values. And that is exactly the pattern observed in Figure 4.b, which graphs the percentage of valid measurements $\left(\mathrm{I}_{\mathrm{XCE}}>\mathrm{I}_{\mathrm{CE}}\right)$ in the entire dataset for different ranges of $\mathrm{R}_{\mathrm{E}}$. The rate was particularly high $(93.9 \%$ to $100 \%)$ for $R_{E}$ values of over $10 \mathrm{k} \Omega$, slid slightly for values of $1 \mathrm{k} \Omega$ to $10 \mathrm{k} \Omega(83.5 \%)$ and declined drastically to just $40 \%$ at $\mathrm{R}_{\mathrm{E}}<1 \mathrm{k} \Omega$.

Of the three environment XS3 structures $(2,7$ and 11) studied, structure 2 had the visibly lowest $R_{E}$ values, most $<1 \mathrm{k} \Omega$ (Figure 4.a), which would explain the high rate of non-valid measurements in that structure. The pattern observed in parameter $R_{E}$ may be associated with concrete resistivity and chloride concentration, given as $\mathrm{wt} \%$ (cement) in Table 2 for some of the structures assessed. Structures 2 and 11,

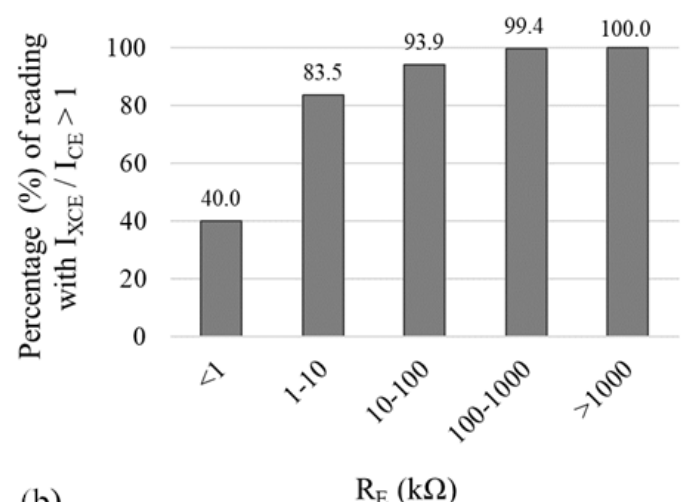

(b)

$$
\mathrm{R}_{\mathrm{E}}(\mathrm{k} \Omega)
$$

FIGURE 4. (a) $\mathrm{I}_{\mathrm{XCE}} / \mathrm{I}_{\mathrm{CE}}$ current ratio vs concrete electrical resistance $\left(\mathrm{R}_{\mathrm{E}}\right)$ obtained with corrosion meter measurements; and (b) percentage of valid measurements $\left(\mathrm{I}_{\mathrm{XCE}} / \mathrm{I}_{\mathrm{CE}}>1\right)$ in all datasets for five ranges of $\mathrm{R}_{\mathrm{E}}$ values. 
On-site corrosion monitoring experience in concrete structures: potential improvements on the current-controlled polarization... 7

TABLE 2. Concrete resistivity and mean chloride concentration on concrete surface and around the reinforcement found for the areas inspected in some of the structures studied.

\begin{tabular}{ccccc}
\hline Structure id. & $\begin{array}{c}\text { Exposure class } \\
\text { as per } \\
\text { EN 206-1 (26) }\end{array}$ & $\begin{array}{c}\text { Resistivity } \\
(\mathrm{k} \Omega \cdot \mathrm{cm})\end{array}$ & $\begin{array}{c}\text { \% Total } \mathrm{Cl}^{-} \text {surface con- } \\
\text { centration } \\
\text { (by cement weight) }\end{array}$ & $\begin{array}{c}\text { \% Total } \mathrm{Cl}^{-} \text {concentration } \\
\text { around the reinforcement } \\
\text { (by cement weight) }\end{array}$ \\
\hline 1 & $\mathrm{XD} 1$ & 23.3 & 0.67 & - \\
2 & $\mathrm{XS3}$ & 8.9 & 2.94 & 2.60 \\
3 & $\mathrm{XC4}$ & 449.6 & 0.28 & 0.12 \\
8 & $\mathrm{XC4}$ & 18.4 & 0.05 & 1.92 \\
9 & $\mathrm{XS} 1$ & 64.1 & 1.49 & 1.12 \\
\hline 11 & $\mathrm{XS} 3$ & 5.2 & 2.80 & \\
\hline
\end{tabular}

exposed to XS3 (high chloride) environments, exhibited resistivities within the same order of magnitude $(8.9 \mathrm{k} \Omega \cdot \mathrm{cm}$ and $5.2 \mathrm{k} \Omega \cdot \mathrm{cm})$ and clearly lower than the others. That finding was related to both the degree of structural saturation and the chloride content in the concrete. Although the total surface chloride concentration was similar in those two structures $(2.94 \%$ in 2 and $2.80 \%$ in 11 ), the total chloride content around the reinforcement, at $2.60 \%$, was substantially higher in 2 than the $1.12 \%$ recorded in 11 .

The foregoing discussion reveals a need to improve the guard ring system used in MCC method, for while its efficacy is acceptable as a rule, the rate of non-valid measurements delivered may be highly unacceptable in low $\mathrm{R}_{\mathrm{E}}$ steel-concrete systems.

\subsection{Reinforcement Polarization Potential}

Figure 5.a graphs measurement reliability with respect to effective reinforcement polarization, i.e., polarization potential $\left(\mathrm{E}_{\mathrm{POL}}\right)$, in keeping with the criteria described in sub-section 2.3, excluding the readings disregarded due to current imbalance in the corrosion meter.

That analysis also excluded structures where the number of measurements deemed as valid in terms of the $\mathrm{E}_{\mathrm{POL}}$ value accounted for less than $3 \%$ of the total, for individualized analysis with so few data would not be reliable. In the eight structures ultimately analyzed, $32.6 \%$ to $66.7 \%$ (mean $=53.7 \%$ ) of the measurements had an $\mathrm{E}_{\mathrm{POL}}$ of $5 \mathrm{mV}$ to $30 \mathrm{mV}$, the range compatible with reliable application of linear polarization resistance. In other words, approximately one of every two measurements was reliable. With such an unacceptably high error rate, valid use of the on-site measuring instrument would be subject to reviewing the $\mathrm{E}_{\mathrm{POL}}$ value for each and every measurement to determine its accuracy and repeat the reading where necessary. That task, not always readily performed in situ, would need to be supplemented with the use of an 'open' device (such as the one adapted for this study) in which all the test parameters are visible, a feature missing in market instruments.

The measurements not reaching effective polarization values suitable for application of the linear polarization resistance method weighed in at $46.3 \%$ of the overall mean. Over-polarization $\left(\mathrm{E}_{\mathrm{POL}}>30 \mathrm{mV}\right)$ prevailed, accounting for $31.6 \%$ compared to the $14.7 \%$ attributable to under-polarization $\left(\mathrm{E}_{\mathrm{POL}}<5 \mathrm{mV}\right)$. That pattern differed from structure to structure when analyzed individually, however. The two types of failure were present to the same extent in structure 8, whilst measurements with

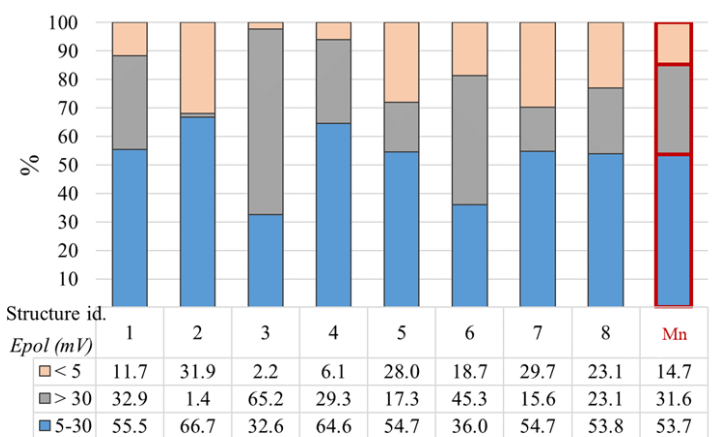

(a)

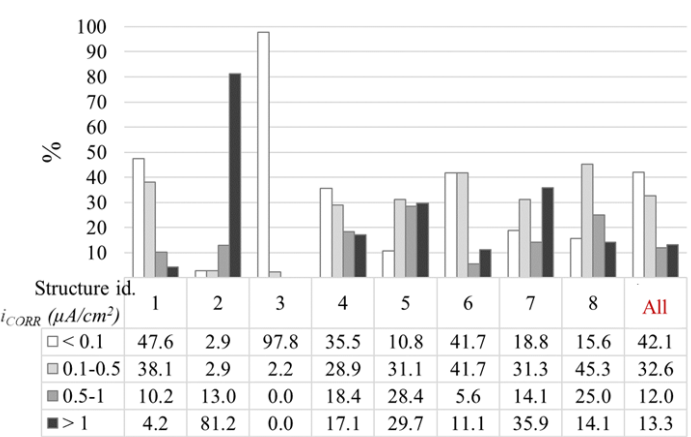

(b)

FIGURE 5. Readings (excluding measurements disregarded due to corrosion meter current imbalance) taken in the eight most representative structures: (a) distribution (\%) by $\mathrm{E}_{\mathrm{POL}}$ range and their mean (Mn); and (b) distribution (\%) by $\mathrm{i}_{\mathrm{CORR}}$ range for each structure individually and as a whole (All). 

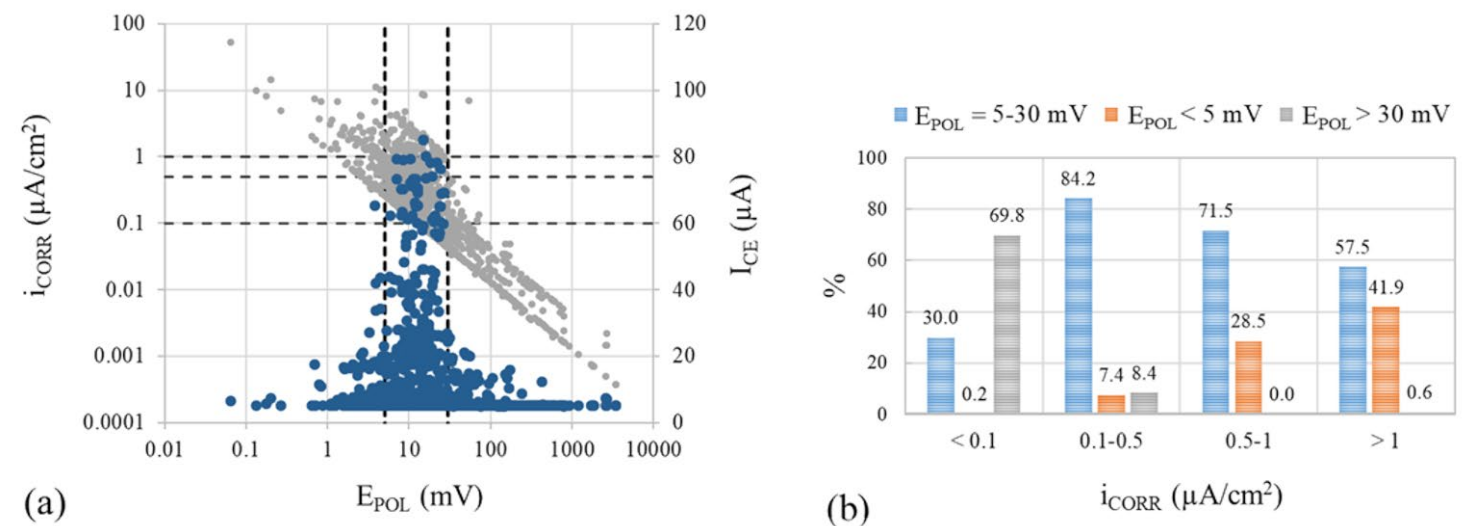

FIGURE 6. Relationship between $\mathrm{E}_{\mathrm{POL}}, \mathrm{I}_{\mathrm{CE}}$ and corrosion density $\left(\mathrm{i}_{\mathrm{CORR}}\right.$ ) (excluding measurements disregarded due to corrosion meter current imbalance) in the eight most representative structures taken as a whole: (a) $\mathrm{i}_{\mathrm{CORR}}$ (grey) and $\mathrm{I}_{\mathrm{CE}}$ (blue) vs $\mathrm{E}_{\mathrm{POL}}$; and (b) distribution (\%) of measurements by $\mathrm{E}_{\mathrm{POL}}$ value in the $\mathrm{i}_{\mathrm{CORR}}$ ranges defined.

$\mathrm{E}_{\mathrm{POL}}<5 \mathrm{mV}$ prevailed in structures 5,7 and especially 2. Measurements with $\mathrm{E}_{\mathrm{POL}}>30 \mathrm{mV}$ predominated in structures 1, 34 and 6 , with structures 3 and 6 exhibiting just $32.6 \%$ and $36 \%$ valid readings, respectively.

Figure 6, in turn, depicts the inter-relationships between $\mathrm{E}_{\mathrm{POL}}, \mathrm{I}_{\mathrm{CE}}$ and corrosion density $\left(\mathrm{i}_{\mathrm{CORR}}\right.$ ) for all eight structures addressed in this sub-section for a more exhaustive analysis of the type of failure (over- or under-polarization). Further to Figure 6.a, $\mathrm{E}_{\mathrm{POL}}$ and $\mathrm{i}_{\mathrm{CORR}}$ were proportionally and indirectly correlated. For $\mathrm{E}_{\mathrm{POL}}$ values lying within the $5 \mathrm{mV}$ to $30 \mathrm{mV}$ interval, $\mathrm{i}_{\text {CORR }}$ ranged from $0.01 \mu \mathrm{A} / \mathrm{cm}^{2}$ to $10 \mu \mathrm{A} / \mathrm{cm}^{2}$ when the $I_{C E}$ value was raised from the minimum device setting of $5 \mu \mathrm{A}$ to a maximum of 80 $\mu \mathrm{A}$. To better visualize this relationship, Figure 6.b graphs the percentage of measurements with $\mathrm{E}_{\mathrm{POL}}<$ $5 \mathrm{mV}, \mathrm{E}_{\mathrm{POL}}>30 \mathrm{mV}$ and $\mathrm{E}_{\mathrm{POL}}=5-30 \mathrm{mV}$ for four ranges of $i_{\text {CORR }}$ values.

The structures with passive reinforcement, i.e., where $\mathrm{i}_{\text {CORR }}$ was $<0.1 \mu \mathrm{A} / \mathrm{cm}^{2}$, exhibited the lowest proportion of measurements with valid $\mathrm{E}_{\mathrm{po}}$ $(5 \mathrm{mV}$ to $30 \mathrm{mV}), 30 \%$. The percentage of valid measurements was highest, at $83.9 \%$, for low cor- rosion ( $\mathrm{i}_{\text {CORR }}$ from $0.1 \mu \mathrm{A} / \mathrm{cm}^{2}$ to $0.5 \mu \mathrm{A} / \mathrm{cm}^{2}$ ), declined to $71.5 \%$ in the presence of moderate corrosion $\left(0.5 \mu \mathrm{A} / \mathrm{cm}^{2}\right.$ to $\left.1 \mu \mathrm{A} / \mathrm{cm}^{2}\right)$ and to $57.5 \%$ where corrosion was high $\left(>1 \mu \mathrm{A} / \mathrm{cm}^{2}\right)$. Where corrosion was moderate or high, the non-valid measurements (28.5\% and $41.9 \%$, respectively) were attributable exclusively to under-polarization $(<5 \mathrm{mV})$ (Figure 6.b). As Figure 6.a shows, such values were obtained because the $\mathrm{I}_{\mathrm{CE}}$ applied proved to be insufficient to raise reinforcement polarization to above the desired threshold. In contrast, in passive reinforcement, where $\mathrm{i}_{\text {CORR }}<0.1 \mu \mathrm{A} / \mathrm{cm}^{2}$, the error $(\approx 70 \%)$ was due exclusively to over-polarization $(>30 \mathrm{mV})$ (Figure 6.b). Although the minimum corrosion meter setting, $\mathrm{I}_{\mathrm{CE}}=5 \mu \mathrm{A}$ (Figure 6.a) was applied in such cases, even that value proved to be too high.

Given those findings, the differences between structures identified in Figure 5.a can be analyzed against the percentage of valid measurements lying within each range of $i_{\text {CORR }}$ values graphed in Figure 5.b. In structures $1,3,4$ and 6 , where the highest percentage of non-valid measurements was observed for $\mathrm{E}_{\mathrm{POL}}>30 \mathrm{mV}$ (Figure 5.a), negligible $\mathrm{i}_{\mathrm{CORR}}$ val-

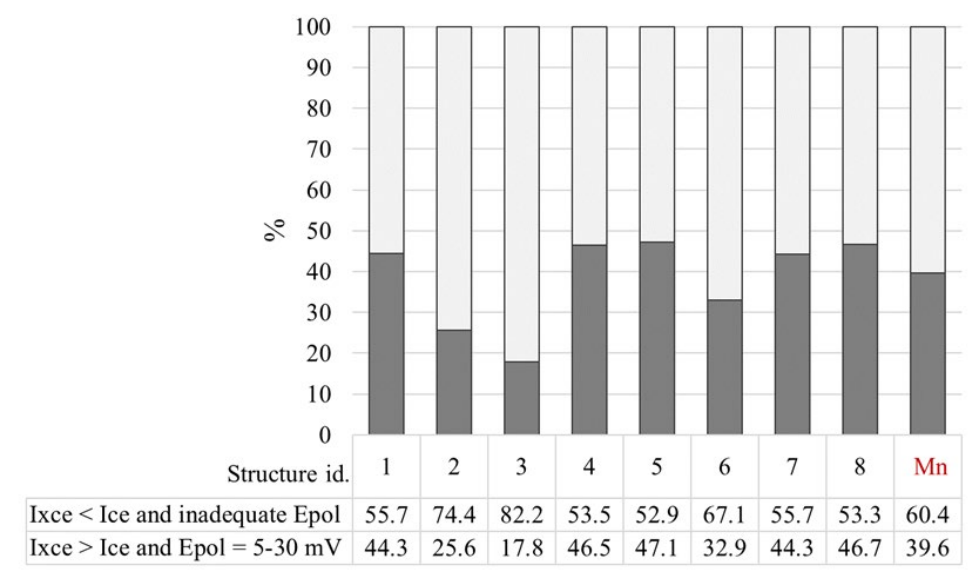

FIGURE 7. Percentage of valid $\left(\mathrm{I}_{\mathrm{XCE}}>\mathrm{I}_{\mathrm{CE}}\right.$ and $\left.\mathrm{E}_{\mathrm{POL}}=5-30 \mathrm{mV}\right)$ and non-valid $\left(\mathrm{I}_{\mathrm{XCE}}<\mathrm{I}_{\mathrm{CE}}\right.$ and inadequate $\left.\mathrm{E}_{\mathrm{POL}}\right)$ readings for the eight structures with a sufficient number of valid measurements for reliable individualized analysis. 

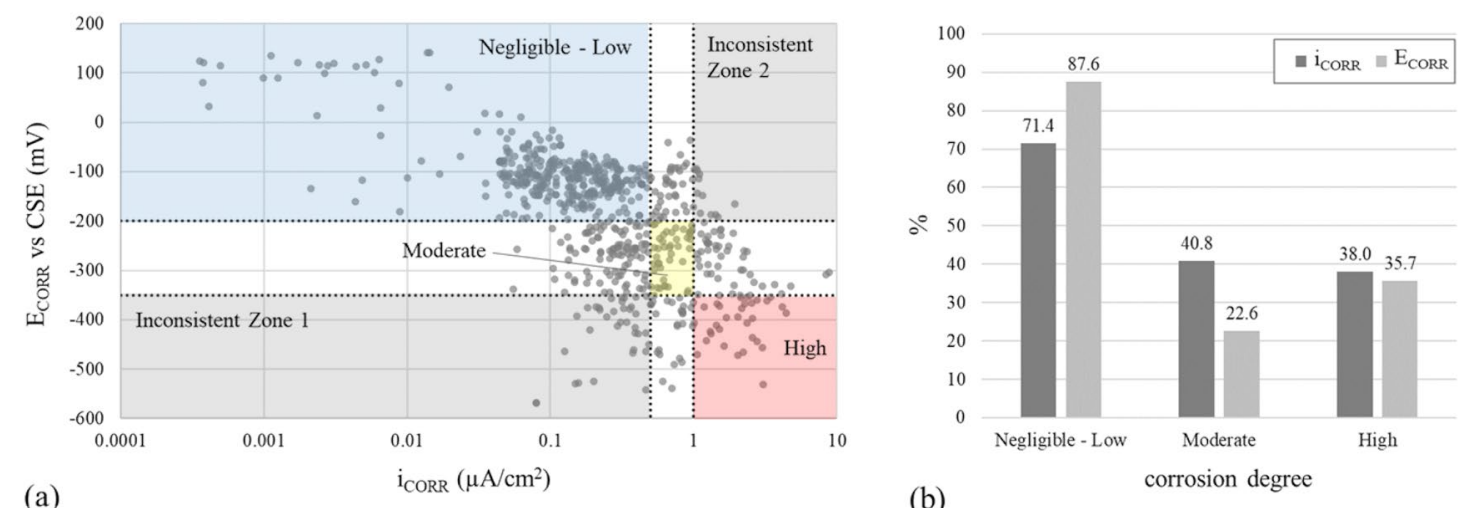

FIGURE 8. Prediction of degree of corrosion by corrosion density $\left(\mathrm{i}_{\mathrm{CORR}}\right)$ and corrosion potential $\left(\mathrm{E}_{\mathrm{CORR}}\right)$ using wholly valid measurements $\left(\mathrm{I}_{\mathrm{XCE}}>\mathrm{I}_{\mathrm{CE}}\right.$ and $\mathrm{E}_{\mathrm{POL}}=5 \mathrm{mV}$ to $30 \mathrm{mV}$ ) made in the eight most representative structures: (a) $\mathrm{i}_{\text {CORR }} \mathrm{VS}_{\mathrm{CORR}}$ by degree of corrosion (negligible-low, moderate and high) as defined in $(31,33)$ and 'inconsistent' zones where the two parameters delivered opposite predictions (zones 1 and 2); and (b) percentage of matching $\mathrm{i}_{\mathrm{CORR}}$ and $\mathrm{E}_{\mathrm{CORR}}$ predictions relative to the total for each parameter separately, by corrosion degree.

ues $\left(<0.1 \mu \mathrm{A} / \mathrm{cm}^{2}\right)$ prevailed. That effect was particularly prominent in structure 3 , where $97.8 \%$ of the measurements showed an $\mathrm{i}_{\mathrm{CORR}}$ of $<0.1 \mu \mathrm{A} / \mathrm{cm}^{2}$, and would explain the $65.2 \%$ of non-valid readings attributable to over-polarization $\left(\mathrm{E}_{\mathrm{POL}}>30 \mathrm{mV}\right)$. In structures 2, 5 and 7 , in turn, non-valid measurements were primarily due to $\mathrm{E}_{\mathrm{POL}}<5 \mathrm{mV}$ (Figure 5.a). The values observed for structure 2 were particularly striking, for nearly all its non-valid readings could be so attributed, a finding by no means unexpected inasmuch as $81.2 \%$ of its total measurements had an $\mathrm{i}_{\text {CORR }}$ of $>1 \mu \mathrm{A} / \mathrm{cm}^{2}$. As noted in sub-section 3.1 , structure 2 was exposed to an XS3 environment with a substantial chloride content, which would explain the high degree of corrosion recorded.

The inference to be drawn from the foregoing is that the MCC method must be improved by optimizing the $\mathrm{I}_{\mathrm{CE}}$ value applied to ensure the polarization $\left(\mathrm{E}_{\mathrm{POL}}\right)$ value remains within the acceptable range in the presence of both active and passive reinforcement.

\section{GENERAL DISCUSSION}

The results discussed in sub-sections 3.1 and 3.2 served as a basis to determine the valid measurements, i.e., with acceptable guard ring performance $\left(\mathrm{I}_{\mathrm{XCE}}>\mathrm{I}_{\mathrm{CE}}\right)$ and polarization values $\left(\mathrm{E}_{\mathrm{POL}}=5 \mathrm{mV}\right.$ to $30 \mathrm{mV}$ ). Figure 7 graphs the valid and non-valid readings for the eight structures discussed in sub-section 3.2 (the ones with $\mathrm{I}_{\mathrm{XCE}}>\mathrm{I}_{\mathrm{CE}}$ and a sufficient number of valid $\mathrm{E}_{\mathrm{POL}}$ values to accommodate individualized analysis). The very low $39.6 \%$ of valid readings could in practice ensure reliable MCC-mediated corrosion rate measurements. Improvements in reliability would call for a device able to display internal measurement parameters (not featured in market instruments) as well as a highly specialized operator to take, review and interpret the readings, and to disregard any failing to meet the established standards.

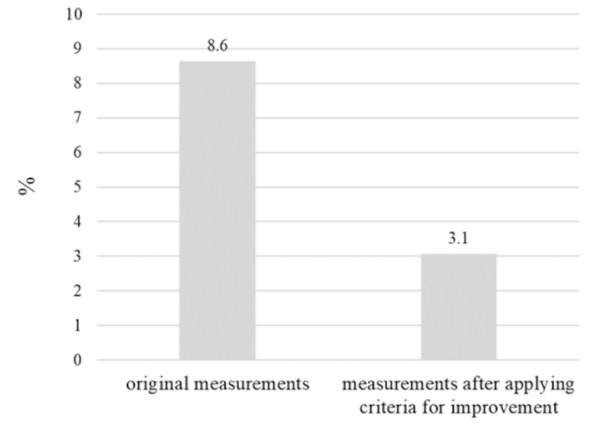

FIGURE 9. Percentage of inconsistent measurements (with $i_{\text {CORR }}$ and $\mathrm{E}_{\mathrm{CORR}}$ values inferring opposite corrosion degreees) relative to total readings, before and after applying the criteria proposed to improve MCC.

That constrains MCC applicability and raises structural inspection times and costs.

Furthermore, the percentage of valid readings was extremely low in some scenarios, such as structures 2 and 3 , whose $25.6 \%$ and $17.8 \%$ validity, respectively, constituted the scenarios where the corrosion meter readings were least reliable. As noted in sub-section 3.1 , in structure 2 the primary source of error was the failure to adequately confine polarization in the reinforcement $\left(\mathrm{I}_{\mathrm{XCE}}<\mathrm{I}_{\mathrm{CE}}\right)$ due to low electrical resistance $\left(\mathrm{R}_{\mathrm{E}}<1 \mathrm{k} \Omega \cdot \mathrm{cm}\right)$ in the concrete cover determined by its very high chloride content (XS3 environment). In structure 3 , in turn, the non-valid readings were related to reinforcement passivity $\left(i_{\text {CORR }}<0.1 \mu \mathrm{A} / \mathrm{cm}^{2}\right)$, which induced over-polarization $\left(\mathrm{E}_{\mathrm{POI}}>30 \mathrm{mV}\right)$, likewise explained in sub-section 3.2. Those findings revealed the need to improve $\mathrm{MCC}$ both to ensure that $\mathrm{I}_{\mathrm{XCE}}>\mathrm{I}_{\mathrm{CE}}$ under the conditions prevailing in the steel-concrete system to be assessed and that $\mathrm{E}_{\mathrm{POL}}$ lies within the 5 to $30 \mathrm{mV}$ range.

Another consideration to be borne in mind is that measurements made with corrosion meters featuring built-in MCC systematically take corrosion potential $\left(\mathrm{E}_{\mathrm{CORR}}\right)$ through the central $\mathrm{Cu} / \mathrm{Cu}_{2} \mathrm{SO}_{4}$ refer- 
ence electrode (CSE) in addition to corrosion density $\left(\mathrm{i}_{\text {CORR }}\right.$ ) readings. Figure 8.a plots $\mathrm{E}_{\text {CORR }}$ against $i_{\text {CORR }}$ for the measurements ultimately deemed valid (Figure 7). Those two parameters were correlated as expected: the more negative the $\mathrm{E}_{\mathrm{CORR}}$ value, the higher the $\mathrm{i}_{\text {CORR }}$ value and vice-versa. They predicted the same degree of corrosion in $62.2 \%$ of the cases. Figure 8.b, graphs the percentage of matching predictions $\left(\mathrm{i}_{\text {CORR }}\right.$-predicted $=\mathrm{E}_{\text {CORR }}$-predicted degree of corrosion) relative to each parameter's individual predictions by degree of corrosion. The highest percentage of matches (a proxy for correct predictions) was observed where corrosion was negligible to low, with $71.4 \%$ matches for $\mathrm{i}_{\mathrm{CORR}}$ and $87.6 \%$ for $\mathrm{E}_{\text {CORR }}$. The percentage of matches for the other corrosion degrees was substantially lower, ranging from $22 \%$ to $41 \%$.

Applying the criteria suggested here for disregarding anomalous in-situ corrosion rate readings (Figure 7) found with the MCC method led to a visible reduction in the percentage of inconsistencies (Figure 9), i.e., cases in which the $i_{\text {CORR }}$ and $E_{\text {CORR }}$ predicted exactly opposite degrees of corrosion (impossible zones 1 and 2 on the graph in Figure 8.a). Inconsistencies ultimately accounted for $3.1 \%$ of the total measurements, down from $8.6 \%$ prior to applying the criteria for improving MCC proposed in this paper. That further justifies the need for such improvements to ensure the reliability of corrosion meter readings irrespective of the scenario studied.

\section{CONCLUSIONS}

This article discusses 1867 in-situ corrosion rate measurements made primarily from 2008 to 2020 with a handheld corrosion meter featuring modulated current confinement (MCC) method. The readings were taken in reinforced concrete structures located in different areas of Spain and consequently exposed to a wide variety of environments. The focus of that discussion is the reliability of the device used with respect to the shortcomings most commonly identified in such instruments: 1) failure of the sensorised guard ring to confine the area of the reinforcement to be polarized; and 2) over- or under-polarization of the reinforcement, detracting from the suitability of the linear polarization resistance method for determining corrosion rate and consequently from measurement reliability. The conclusions drawn are set out below.

- The sensorised guard ring deployed in the MCC method worked efficiently in $74 \%$ of the cases studied. The inference of that finding is that as the galvanostatic current applied to polarize the reinforcement by the guard ring's external counter electrode $\left(\mathrm{I}_{\mathrm{XCE}}\right)$ was greater than applied by the internal counter electrode $\left(\mathrm{I}_{\mathrm{CE}}\right)$, rebar polarization remained within the desired range. An analysis of the entire universe of inspections re- vealed that as concrete electrical resistance $\left(\mathrm{R}_{\mathrm{E}}\right)$ declined, the likelihood of guard ring failure $\left(\mathrm{I}_{\mathrm{XCE}}<\mathrm{I}_{\mathrm{CE}}\right)$ rose, delivering non-valid measurements in $60 \%$ of structures with $\mathrm{R}_{\mathrm{E}}<1 \mathrm{k} \Omega \cdot \mathrm{cm}$ due to chloride contamination.

- In the measurements where the guard ring was effective, reinforcement polarization $\left(\mathrm{E}_{\mathrm{POL}}\right)$ was standard-compliant in $53.7 \%$ of cases. That meant that the $\mathrm{I}_{\mathrm{CE}}$ applied resulted in an $\mathrm{E}_{\mathrm{POL}}$ of $5 \mathrm{mV}$ to $30 \mathrm{mV}$, the range in which linear polarization resistance can be reliably applied to calculate corrosion rate. Where the degree of rebar corrosion was high $\left(\mathrm{i}_{\text {CORR }}>1 \mu \mathrm{A} / \mathrm{cm}^{2}\right)$, measurement non-validity was primarily attributable to under-polarization $\left(\mathrm{E}_{\mathrm{POL}}<\right.$ $5 \mathrm{mV})$. Where the steel was passive $\left(\mathrm{i}_{\text {CORR }}<0.1\right.$ $\mu \mathrm{A} / \mathrm{cm}^{2}$ ), the percentage of valid readings declined to drastically below the mean due to reinforcement over-polarization $\left(\mathrm{E}_{\mathrm{POL}}>30 \mathrm{mV}\right)$.

- In all, 39.6\% of the measurements were ultimately found to be valid, with standard-compliant guard ring performance and polarization. That percentage varied widely, however, depending on the degree of reinforcement corrosion (passive or active) and the electrical resistance of the concrete cover in the structure inspected. The scenarios least favorable for MCC-mediated in-situ corrosion rate measurements were observed in structures with low concrete electrical resistance and/or passive reinforcing steel.

- The improvements to the MCC method identified in this study would attempt to ensure effective confinement of the target area in the reinforcement $\left(\mathrm{I}_{\mathrm{XCE}}>\mathrm{I}_{\mathrm{CE}}\right)$ and appropriate polarization $\left(\mathrm{E}_{\mathrm{POL}}=5 \mathrm{mV}\right.$ to $\left.30 \mathrm{mV}\right)$. The aim is to prevent measurement reliability from varying depending on the skill of the operator taking, reviewing and interpreting readings. The findings reported here are being applied by the research team to develop reliable corrosion meters that can be successfully used in structural health monitoring. Their results, promising at this writing, will be addressed in future papers.

\section{AUTHOR CONTRIBUTIONS:}

Conceptualization: I. Martínez A. Castillo; Data curation: I. Martínez; Formal analysis: J.E. Ramón, I. Martínez; Funding acquisition: I. Martínez, A. Castillo; Investigation: I. Martínez, A. Castillo, J.E. Ramón; Methodology: I. Martínez J.E. Ramón; Project administration: I. Martínez; Resources: I. Martínez, A. Castillo; Software: J.E. Ramón; Supervision: I. Martínez; Validation: I. Martínez; Visualization; Roles/Writing - original draft: J.E Ramón; Writing - review \& editing: I. Martínez.

\section{REFERENCES}

1. EN 1992-1-1: Eurocode 2: Design of concrete structures Part 1-1: General rules and rules for buildings, CEN, 2015.

2. Martínez, I.; Andrade, C. (2011) Polarization resistance measurements of bars embedded in concrete with different 
chloride concentrations: EIS and DC comparison. Mater. Corros. 62 [10], 932-942. https://doi.org/10.1002/ maco.200905596.

3. Scully, J.R. (2000) Polarization resistance method for determination of instantaneous corrosion rates. Corros. 56 [2], 199-218. https://doi.org/10.5006/1.3280536.

4. So, H.S.; Millard, S.G. (2007) Assessment of corrosion rate of reinforcing steel in concrete using Galvanostatic pulse transient technique. Int. of Concrete. Str. and Mat. 1 [1], 8388. https://doi.org/10.4334/IJCSM.2007.1.1.083.

5. Gonzalez, J.A.; Albeniz, J.; Feliu, S. (1996) Polarization resistance constant $\mathrm{B}$ values for 20 different metalenvironment systems. Rev. Metal. 32 [1], 10-7.

6. Andrade, C.; Alonso, C. (2004) Test methods for on-site corrosion rate measurement of steel reinforcement in concrete by means of the polarization resistance method. Mat. Struct. 37 [9], 623-643. https://doi.org/10.1007/BF02483292.

7. Feliu, S.; Gonzalez, J.A.; Feliu, V.; Escudero, L.; Rodriguez, I.A.; Ausin, V.; et al. inventors; CSIC Consejo Superior Investigaciones Científicas; Geotec Cimientos; Geotecnia y Cimientos Geocisa Sa; Consejo Superior Investigacion, assignee. Electrochemical measuring-corrosion rate of reinforcement in concrete-using DC to obtain corrosion rate taking into account reinforcement area affected by electrical signal patent CA2042883-A; ES2024268-A; US5259944-A.

8. Krebs, N.; Fabrin, K.; Frolund, T.; Kofoed, B.; Langkjaer, C.; Klinghoffer, O. inventors; Force Inst, assignee. Determining rate of corrosion in reinforced concrete-uses galvanostatic pulse method in connection with reference electrode and current density controlled counterelectrode patent WO9709603-A1; DK9500981-A; AU9667860-A; DK171925-B

9. Elsener, B. (2005) Corrosion rate of steel in concreteMeasurements beyond the Tafel law. Corr. Sci. 47 [12], 30193033. https://doi.org/10.1016/j.corsci.2005.06.021

10. Frølund, T.; Jensen, M.F.; Bassler, R. (2002) Determination of reinforcement corrosion rate by means of the galvanostatic pulse technique. In First International Conference on Bridge Maintenance, Safety and Management IABMAS. Barcelona (Spain), 14-17 July.

11. Vedalakshmi, R.; Balamurugan, L.; Saraswathy, V.; Kim, S.H.; Ann, K.Y. (2010) Reliability of galvanostatic pulse technique in assessing the corrosion rate of rebar in concrete structures: Laboratory vs field studies. KSCE J. Civil Engineer. 14 [6], 867-877. https://doi.org/10.1007/s12205010-1023-6.

12. Xu, J.; Yao, W. (2010) Detecting the efficiency of cathodic protection in reinforced concrete by use of galvanostatic pulse technique. Adv. Mat. Res. 177, 584-589. https://doi. org/10.4028/www.scientific.net/AMR.177.584.

13. Dou, Y.T.; Hao, B.H.; Meng, B.; Xie, J.; Dong, M.L.; Zhang, A.L. (2014) The study to the corrosion of reinforcing steel in concrete by using galvanostatic pulse technique. Appl. Mech. Mater. 501, 916-919. https://doi.org/10.4028/www.scientific. net/AMM.501-504.916.

14. Martínez, I.; Andrade, C.; Rebolledo, N.; Bouteiller, V.; MarieVictoire, E.; Olivier, G. (2008) Corrosion characterization of reinforced concrete slabs with different devices. Corrosion. 64 [2], 107-123. https://doi.org/10.5006/1.3280679.

15. Poursaee, A.; Hansson, C.M. (2008) Galvanostatic pulse technique with the current confinement guard ring: The laboratory and finite element analysis. Corros. Sci. 50 [10], 2739-2746. https://doi.org/10.1016/j.corsci.2008.07.017.

16. Martínez, I;; Andrade, C.; Rebolledo, N.; Luo, L.; De Schutter, G. (2010) Corrosion-inhibitor efficiency control: comparison by means of different portable corrosion rate meters. Corrosion. 66 [2], 026001-026001-12. https://doi. org $/ 10.5006 / 1.3319663$

17. Feliu, S.; González, J.A.; Feliu, S.Jr.; Andrade, C. (1990) Confinement of the electrical signal for in situ measurement of polarization resistance in reinforced concrete. ACI Mater. J. 87 [5], 457-60.

18. Martínez, I.; Andrade, C.; Fullea, J.; Bolano, J.A.; Jimenez, F.; Navarro, A. inventors; Consejo Superior de Investigaciones Cientificas (CNSJ-C) Geotecnia \& Cimientos GEOCISA SA (GEOT-Non-standard) assignee. Method and device used to detect corrosion in cathodically-protected buried steel patent WO200203330-A1; ES2180440-A1; ES2180440-B1; AU2002314213-A1.

19. Martínez, I.; Andrade, C.; Fullea, J.; Castellote, M. inventors Consejo Superior de Investigaciones Cientificas (CONSNon-standard), assignee. Method for measuring speed of corrosion in metal by induced polarization, involves maintaining two electrodes in contact with metal in order to carry out measurement, where electrodes are located in two intermediate points patent ES2237241-A1; ES2237241-B1

20. Ramón, J.E.; Martínez, I.; Gandía-Romero, J.M.; Soto, J. (2021) An embedded-sensor approach for concrete resistivity measurement in on-site corrosion monitoring: cell constants determination. Sensors. 21 [7], 2481. https://doi.org/10.3390/ s21072481.

21. Martínez, I.; Andrade, C.; Castillo, A. (2012) Corrosion evaluation in nuclear contention structures using electrochemical nondestructive techniques. Inf. Construcc. 64 [528], 519-528. https://doi.org/10.3989/ic.11.103.

22. Castillo,A.; Andrade, C.; Martínez, I.; Rebolledo, N.; FernándezTroyano, L.; Ayuso, G.; Cuervo, J.; Junquera, J.; Santana, C.; Delgado, J. (2011) Assessment and monitoring of durability of shell structures in "Zarzuela Racecourse" Madrid. Inf. Construcc. 63 [524], 33-41. https://doi.org/10.3989/ic10.058.

23. Martínez, I.; Andrade, C. (2009) Examples of reinforcement corrosion monitoring by embedded sensors in concrete structures. Cem. Concr. Compos. 31 [8], 545-554. https://doi. org/10.1016/j.cemconcomp.2009.05.007.

24. Andrade, C.; Martínez, I.; Castellote, M. (2008) Feasibility of determining corrosion rates by means of stray currentinduced polarization. J. Appl. Electrochem. 38 [10], 14671476. https://doi.org/10.1007/s10800-008-9591-6.

25. Andrade, C.; Martínez, I. (2005) Calibration by gravimetric losses of electrochemical corrosion rate measurement using modulated confinement of the current. Mat. Struct. 38 [9], 833-841. https://doi.org/10.1007/BF02481656.

26. EN 206:2013+A2:2021. Concrete-Part 1: Specification, performance, production and conformity. British Standards Institution, 2021

27. Newman, J. (1966) Resistance for flow of current to a disk. J. Electrochem. Soc. 113 [5], 501-502. https://doi. org/10.1149/1.2424003.

28. Feliu, S.; Andrade, C.; González, J.A.; Alonso, C. (1996) A new method for in-situ measurement of electrical resistivity of reinforced concrete. Mat. Struct. 29 [6], 362-365. https:// doi.org/10.1007/BF02486344.

29. UNE 112010:2011 Spanish Standard, Corrosion of concrete reinforcement steel. Chloride determination for in-service concrete, 2011

30. Feliu, V.; González, J.A.; Andrade, C.; Feliu, S. (1998) Equivalent circuit for modelling the steel-concrete interface. I. Experimental evidence and theoretical predictions. Corros. Sci. 40 [6], 975-993. https://doi.org/10.1016/S0010938X(98)00036-5.

31. UNE 112072:2011 Spanish Standard, Laboratory measurement of corrosion rate using the polarization resistance technique, 2011.

32. Andrade, C.; Alonso, M.C.; González, J.A. (1990) An initial effort to use the corrosion rate measurements for estimating rebar durability. In: Berke, N.S.; Chaker, V.; Whiting, D. editors. Corrosion rates of steel in concrete ASTM STP1065. Philadelphia: Am. Soc. Tes. Mat. 143.

33. ASTM C876 - 15, Standard Test Method for Corrosion Potentials of Uncoated Reinforcing Steel in Concrete. West Conshohocken, PA, 2015

34. Polder, R.B. (2001) Test methods for on site measurement of resistivity of concrete-A RILEM TC-154 technical recommendation. Constr. Build. Mater. 15 [2-3], 125-131. https://doi.org/10.1016/S0950-0618(00)00061-1.

35. Andrade, C.; Martínez, I.; Alonso, C.; Fullea, J. (2001) New advanced electrochemical techniques/or on site measurements of reinforcement corrosion. Mat. Constr. 51 [263-264], 97-107. https://doi.org/10.3989/mc.2001.v51.i263-264.356

36. Martínez, I.; Castillo, A. (2020) Concrete surface applied corrosion inhibitors: on site evaluation by non-destructive electrochemical techniques. In REHABEND 2020 Congress Granada (Spain), 24-27 March, 2020. https://hdl.handle. net/10261/234898 